\title{
Metabolic Coupling of Dehydration and Decarboxylation in the Curacin A Pathway: Functional Identification of a Mechanistically Diverse Enzyme Pair
}

\author{
Liangcai Gu, ${ }^{\dagger}$ Junyong Jia, ${ }^{\dagger}$ Haichuan Liu, ${ }^{\ddagger}$ Kristina Håkansson, ${ }^{\ddagger}$ \\ William H. Gerwick, ${ }^{\S}$ and David H. Sherman ${ }^{\dagger, \pi, *}$ \\ Life Sciences Institute, Department of Medicinal Chemistry, Department of \\ Chemistry, and Department of Microbiology \& Immunology, University of \\ Michigan, Ann Arbor, Michigan 48109, Scripps Institution of \\ Oceanography, University of California at San Diego, La Jolla, California \\ 92093
}

\section{Supporting Information}

Chemical synthesis of 3-methyl-3-butenoyl CoA. 3-methyl-3-butenoic acid was prepared by oxidizing 3-methyl-3-buten-1-ol (Fluka) using $\mathrm{CrO}_{3} / \mathrm{H}_{2} \mathrm{SO}_{4}$. Analytical data: ${ }^{1} \mathrm{H}$ NMR $\left(300 \mathrm{MHz}, \mathrm{CD}_{3} \mathrm{Cl}\right): \delta=1.83$ (s, 3H), $3.06(\mathrm{~s}, 2 \mathrm{H}), 4.88(\mathrm{~s}, 1 \mathrm{H}), 4.94(\mathrm{~s}, 1 \mathrm{H})$. 3-methyl-3-butenoyl CoA was generated by the thioesterification reaction of coenzyme A (protocol from Professor Christopher T. Walsh). $6.5 \mu \mathrm{L}$ 3-methyl-3-butenoic acid solution (100 mg/mL acid in THF), $200 \mu \mathrm{L}$ (benzotriazol-1-yloxy) tripyrrolidinophosphonium hexafluorophosphate (PyBOP) suspension $(66.5 \mathrm{mg} / \mathrm{mL}$ in THF) and $8.87 \mu \mathrm{L}$ $\mathrm{N}, \mathrm{N}$-Diisopropylethylamine (DIPEA) were combined before adding $200 \mu \mathrm{L}$ CoA solution $(50 \mathrm{mg} / \mathrm{mL})$. Reaction mixture was stirred for 3-5 hours at room temperature. The mixture was loaded onto a preparative $\mathrm{C}_{18}$ column, and eluted with the gradient of 5-50\% $\mathrm{CH}_{3} \mathrm{OH} / \mathrm{H}_{2} \mathrm{O} \quad\left(10 \mathrm{mM} \quad \mathrm{NH}_{4} \mathrm{OAc}\right)$. Further purification was performed using a semipreparative $\mathrm{C}_{18}$ column and the gradient of $5-40 \% \mathrm{CH}_{3} \mathrm{OH} / \mathrm{H}_{2} \mathrm{O}\left(10 \mathrm{mM} \mathrm{NH} \mathrm{NH}_{4} \mathrm{OAc}\right)$. Analytical data: ESI-MS (-ve): expected [M-H]: 848.2, found: 848.3.

Enzymatic synthesis of (S)-HMG-CoA. (S)-HMG-CoA was enzymatically generated using HMG-CoA reductase as previously described. ${ }^{1}$ The $15 \mathrm{ml}$ reaction mixture contained $60 \mathrm{mM}$ Tris- $\mathrm{HCl}$, pH 7.9, $60 \mathrm{mM}(R, S)$-mevalonate, $5 \mathrm{mM} \mathrm{NAD}{ }^{+}, 1 \mathrm{mM} \mathrm{CoA}$ and $150 \mathrm{mM}$ HMG-CoA reductase. $60 \mathrm{mM}$ pyruvate and lactate dehydrogenase (200 units) were added to regenerate $\mathrm{NAD}^{+}$. The reaction was stirred at room temperature for 3 hours and monitored at UV $340 \mathrm{~nm}$. The precipitate and enzymes were removed from the solution using a $10 \mathrm{kDa}$ cutoff membrane (Amicon Ultra, Millipore). The filtrated solution was applied to a preparative $\mathrm{C}_{18}$ column using the elution gradient of $3-60 \% \mathrm{CH}_{3} \mathrm{OH} / \mathrm{H}_{2} \mathrm{O}(10$ $\mathrm{mM} \mathrm{NH} \mathrm{N}_{4} \mathrm{OAc}$ ). The collected fraction containing (S)-HMG-CoA was evaporated and lyophilized. (S)-HMG-CoA was further purified by a semipreparative $\mathrm{C}_{18}$ column using the elution gradient of 3-30\% $\mathrm{CH}_{3} \mathrm{OH} / \mathrm{H}_{2} \mathrm{O}\left(10 \mathrm{mM} \mathrm{NH} \mathrm{N}_{4} \mathrm{OAc}\right)$. Analytical data: ESI-MS (-ve): expected [M-H]: 910.2 , found: 910.3 .

Bacterial strains, media and culture conditions. Escherichia coli DH5 $\alpha$ MCR (Invitrogen) was used for DNA propagation. Escherichia coli BL21 (DE3) (Invitrogen) transformed with the derivatives of pET24b and pET28b (Novagen) was used for protein overexpression in Luria-Bertani (LB) medium. Ampicillin $(100 \mu \mathrm{g} / \mathrm{mL})$, Kanamycin (50 $\mu \mathrm{g} / \mathrm{mL})$, Chloramphenicol $(25 \mu \mathrm{g} / \mathrm{mL})$, and Apramycin $(50 \mu \mathrm{g} / \mathrm{mL})$ were used for the corresponding plasmid construct resistance marker selection in E. coli cultures.

Plasmid construction and protein overexpression. $\mathrm{CurB}$, $\mathrm{CurE}$ and $\mathrm{CurF}-\mathrm{ECH}_{2}$ 
(1-259 amino acid) genes were amplified from cosmid pLM54 described in our previous study $^{2}$ and inserted into pET24b and pET28b plasmids by the NdeI and XhoI restriction sites. The oligo pairs used for PCR amplification are the following: CurB ((F) 5'-ATT GGA GTT CAT ATG AGC AAA GAA CAA GTA-3', (R) 5'-CAA CAA CTC GAG CAA TTT TGC TGC AAA TCA G-3'), CurE ((F) 5'-GAA CAC TAT CAT ATG TAT TAC AAA ACC ATA-3', (R) 5'-GAT TCA CTC GAG GTT CTG CCA TGG GTA ATA-3') and CurF-ECH $_{2}$ ((F) 5'-CAT ATG GCA GAA CTG AAT TTG AAT-3', (R) 5'-CTC GAG AAA CTC TTG CTG AAT ACG ACT-3'). The plasmid constructions were sequenced to confirm that they contained no errors. E. coli BL21 (DE3) was transformed by the expression plasmids, pET28b::CurE, pET24b::CurF-ECH ${ }_{2}$ and pET28b::CurB, to express N-His-tagged CurE, C-His-tagged CurF-ECH ${ }_{2}$, and N-His-tagged CurB. 0.8 liter cultures were inoculated with $8 \mathrm{ml}$ of an overnight culture grown at $37^{\circ} \mathrm{C}$. For CurB and $\mathrm{CurF}-\mathrm{ECH}_{2}$, the cultures were grown at $35^{\circ} \mathrm{C}$ to an $\mathrm{OD}(600 \mathrm{~nm})=0.5$, and then cooled to $18{ }^{\circ} \mathrm{C}$ prior to the addition of isopropyl- $\beta$-D-galactopyranoside (IPTG) (final concentration is $1 \mathrm{mM}$ ). The cultures were grown at $18^{\circ} \mathrm{C}$ for another $10-12 \mathrm{~h}$. In order to increase the solubility of CurE, the pG-KJE8 chaperone system (TaKaRa) was used to coexpress the chaperones in E. coli according to the instruction manual. $2.0 \mathrm{mg} / \mathrm{mL} L$-arabinose and $5 \mathrm{ng} / \mathrm{mL}$ tetracycline were added to the culture to induce the chaperone expression. The culture was grown at $30^{\circ} \mathrm{C}$ to an OD $(600 \mathrm{~nm})=0.3-0.4$, and cooled to $22^{\circ} \mathrm{C}$ before the addition of IPTG $(0.5 \mathrm{mM})$. The culture was grown at $18^{\circ} \mathrm{C}$ for another $7-8 \mathrm{~h}$ prior to harvesting.

Protein purification. Protein purification was performed at $4^{\circ} \mathrm{C}$. E. coli cells bearing an expression construct were harvested by centrifugation $\left(4,000 \times \mathrm{g}, 15 \mathrm{~min}, 4^{\circ} \mathrm{C}\right)$, resuspended in the lysis buffer $(50 \mathrm{mM}$ PBS buffer, $\mathrm{pH} 8.0,300 \mathrm{mM} \mathrm{NaCl}, 10 \mathrm{mM}$ imidazole, $20 \%$ glycerol) and disrupted by sonication. The cell debris was removed by centrifugation at $15,000 \times g$ for $50 \mathrm{~min}$. The supernatant was gently removed and loaded onto at the Ni-NTA agarose column pre-equilibrated with lysis buffer. The resin was washed successively with at least 5 column volumes of the washing buffer (50 mM PBS buffer, $\mathrm{pH} 8.0,300 \mathrm{mM} \mathrm{NaCl}, 20 \mathrm{mM}$ imidazole) to remove nonspecifically bound contaminants. Bound proteins were eluted with the elution buffer (50 mM PBS buffer, $\mathrm{pH}$ $8.0,300 \mathrm{mM} \mathrm{NaCl}, 250 \mathrm{mM}$ imidazole). The eluate was concentrated using Amicon Ultra centrifugal devices (Millipore) and immediately loaded onto the PD10 desalting column (GE Healthcare) pre-equilibrated with the storage buffer (50 mM PBS buffer, $\mathrm{pH} 7.5,200$ $\mathrm{mM} \mathrm{NaCl}, 20 \%$ glycerol). The proteins were flash-frozen in liquid $\mathrm{N}_{2}$ and stored at $-80^{\circ} \mathrm{C}$ for further use. The purity of the protein was analyzed by SDS-PAGE and the protein concentrations were determined using the Bradford assay (Bio-Rad Protein assay, Bio-Rad).

CurB substrate loading and ECH activity assays. (R,S)-HMG was loaded onto CurB via in vitro phosphopantetheinylation. ${ }^{3} 50 \mu \mathrm{M}$ apo-CurB was incubated with $500 \mu \mathrm{M}$ $(R, S)$-HMG-CoA, $4 \mu \mathrm{M} \mathrm{Sfp,} 10 \mathrm{mM} \mathrm{MgCl}{ }_{2}$ in $50 \mathrm{mM}$ Tris- $\mathrm{HCl}$ buffer, $\mathrm{pH} 8.1$ at $30^{\circ} \mathrm{C}$ for 3 h. The $(R, S)$-HMG-holo-CurB was dialysis against $30 \mathrm{mM}$ Bis-Tris buffer, $\mathrm{pH} 6.5$ at $4^{\circ} \mathrm{C}$ for overnight to remove the excess HMG-CoA. ECH assays were performed by incubating $50 \mu \mathrm{M}(R, S)$-HMG-holo-CurB and $2 \mu \mathrm{M} \mathrm{ECH}_{1}, \mathrm{ECH}_{2}$ or both at 25,30 and $37^{\circ} \mathrm{C}$ for $3 \mathrm{~h}$. A Source 15PRC reverse phase column (GE Healthcare) was employed to purify CurB from the reaction mixtures before ESI-FTMS analysis. CurB was eluted out at $\sim 55 \%$ $\mathrm{CH}_{3} \mathrm{CN}\left(0.05 \% \mathrm{HCOOH}\right.$ and $\left.0.05 \% \quad \mathrm{CF}_{3} \mathrm{COOH}\right) / \mathrm{H}_{2} \mathrm{O} \quad(0.05 \% \mathrm{HCOOH}$ and $0.05 \%$ $\left.\mathrm{CF}_{3} \mathrm{COOH}\right)$.

FTMS analysis. Multiply protonated $(R, S)$-HMG-holo-CurB with or without $\mathrm{ECH}_{1}$ 
and/or $\mathrm{ECH}_{2}$ treatment was generated by electrospray ionization (ESI) at $70 \mu \mathrm{L} / \mathrm{h}$ (Apollo ion source, Bruker Daltonics, Billerica, MA) of a solution containing $2.5 \mu \mathrm{M}(R, S)$-HMGholo-CurB (1:1 $\mathrm{CH}_{3} \mathrm{CN}: \mathrm{H}_{2} \mathrm{O}$ with $0.05 \% \mathrm{HCOOH}$ and $\left.0.05 \% \mathrm{CF}_{3} \mathrm{COOH}\right)$. To accurately determine the masses of HMG-holo-CurB and the species associated with the loss of $\mathrm{H}_{2} \mathrm{O}$ and $\left(\mathrm{H}_{2} \mathrm{O}+\mathrm{CO}_{2}\right)$ from $(R, S)$-HMG-holo-CurB a calibration standard (G2421A, Agilent Technologies, Palo Alto, CA) was mixed with the sample (30-fold dilution of the standard) for internal calibration. All mass spectra were collected with an actively shielded 7 Tesla quadrupole-Fourier transform ion cyclotron resonance (FT-ICR) mass spectrometer (APEX-Q, Bruker Daltonics). Ions produced by ESI were externally accumulated in a hexapole for $1 \mathrm{~s}$, transferred via high voltage ion optics, and captured in an Infinity ICR cell $^{4}$ by gated trapping. This accumulation sequence was looped 32 times. The ESI capillary voltage was set to $-3.8 \mathrm{kV}$. Nitrogen drying gas $\left(200-250^{\circ} \mathrm{C}\right)$ was employed to assist desolvation of ESI droplets. The collision cell gas pressure (Ar) was kept at $4.5 \times$ $10^{-6}$ mbar, which is slightly lower than the standard pressure used for this instrument (6-7 $\times 10^{-6} \mathrm{mbar}$ ). All data were acquired with XMASS software (version 6.1, Bruker Daltonics) in broadband mode from $\mathrm{m} / \mathrm{z}=200$ to 2000 with $512 \mathrm{k}$ data points and summed over 16 or 32 scans. Mass spectra were analyzed with the MIDAS analysis software. ${ }^{5}$ Internal frequency-to-mass calibration was performed by Microsoft Excel with a two-term calibration equation ${ }^{6}$ using the masses of two peaks $(\mathrm{m} / \mathrm{z}=622.02895$ and 922.00979) resulting from the calibration standard.

HPLC and mass spectrometry analysis. The ECH activity assays using HMG-CoA substrate were performed by incubating $500 \mu \mathrm{M} \mathrm{HMG}-\mathrm{CoA}$ and $2 \mu \mathrm{M} \mathrm{ECH}, \mathrm{ECH}_{2}$ or both in $30 \mathrm{mM}$ Bis-Tris-HCl buffer, $\mathrm{pH} 6.5$ at $37^{\circ} \mathrm{C}$ for $5 \mathrm{~h}$. Before the LC-MS analysis, the reaction mixtures were filtered using a $10 \mathrm{kDa}$ cutoff membrane $(0.5 \mathrm{ml}$, Amicon Microcon, Millipore) to remove the enzymes. The filtered mixtures were analyzed by HPLC using a reverse-phase column chromatography (XBridge C18, $3.5 \mu \mathrm{m}, 2.1 \times 150 \mathrm{~mm}$, Waters). The LC-MS was performed on the ThermoElectron Surveyor HPLC system equipped with the ThermoElectron Finnigan ESI-LTQ mass spectrometer. The isolation width for MS/MS-fragmentation was 1.5 and the normalized energy was set to $28 \%$.

Supplementary Data (see the following pages)

\section{References}

(1) Bischoff, K. M.; Rodwell, V. W. Biochem. Med. Metab. Biol. 1992, 48, 149-158.

(2) Chang, Z. X.; Sitachitta, N.; Rossi, J. V.; Roberts, M. A.; Flatt, P. M.; Jia, J. Y.; Sherman, D. H.; Gerwick, W. H. J. Nat. Prod. 2004, 67, 1356-1367.

(3) Lambalot, R. H.; Gehring, A. M.; Flugel, R. S.; Zuber, P.; LaCelle, M.; Marahiel, M. A.; Reid, R.; Khosla, C.; Walsh, C. T. Chem. Biol. 1996, 3, 923-936.

(4) Caravatti, P.; Allemann, M. Org. Mass Spectrom. 1991, 26, 514-518.

(5) Senko, M. W.; Canterbury, J. D.; Guan, S. H.; Marshall, A. G. Rapid Commun. Mass Sp. 1996, 10, 1839-1844.

(6) Ledford, E. B.; Rempel, D. L.; Gross, M. L. Anal. Chem.1984, 56, 2744-2748.

\footnotetext{
${ }^{\dagger}$ Life Sciences Institute, Department of Medicinal Chemistry, University of Michigan

₹ Department of Chemistry, University of Michigan

"Department of Microbiology \& Immunology, University of Michigan

${ }^{\S}$ Scripps Institution of Oceanography, University of California at San Diego
} 
A

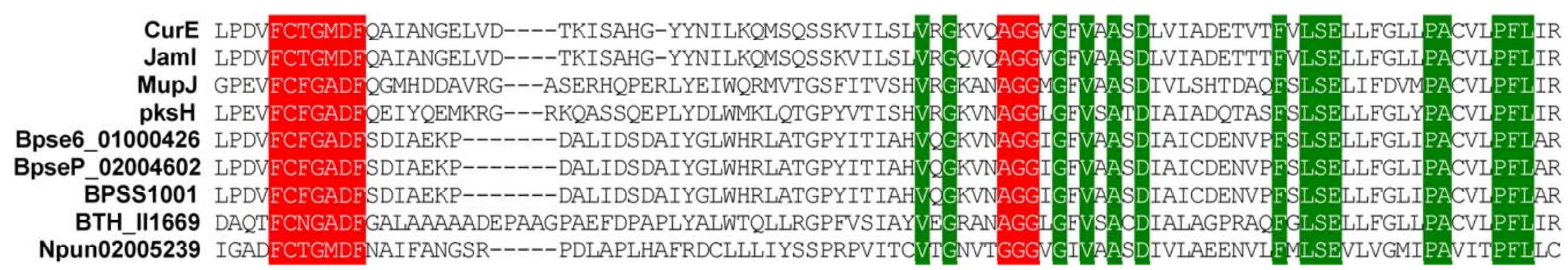

B

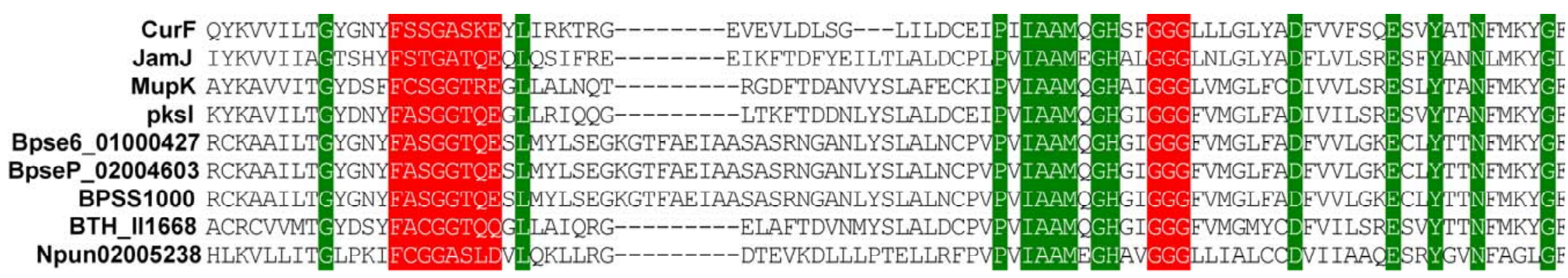

Figure 1. Partial sequence alignments of $\mathrm{ECH}_{1}(\mathbf{A})$ and $\mathrm{ECH}_{2}(\mathbf{B})$ from different microorganisms. The two consensus sequences highlighted in red were reported to contribute to the formation of the oxyanion hole in the crotonase superfamily. The identical amino acids are highlighted in green. CurE, F: Lyngbya majuscula; JamI, J: Lyngbya majuscula; MupJ, K: Pseudomonas fluorescens; PksH, I: Bacillus subtilis; Bpse6_01000426, 01000427, Burkholderia pseudomallei; BpseP_02004602, 02004603: Burkholderia pseudomallēi; BPSS1000, 1001: Burkholderia pseudomallei; BTH_II1668, 1669: Burkholderia thailandensis; Npun02005238, 02005239: Nostoc punctiforme. 


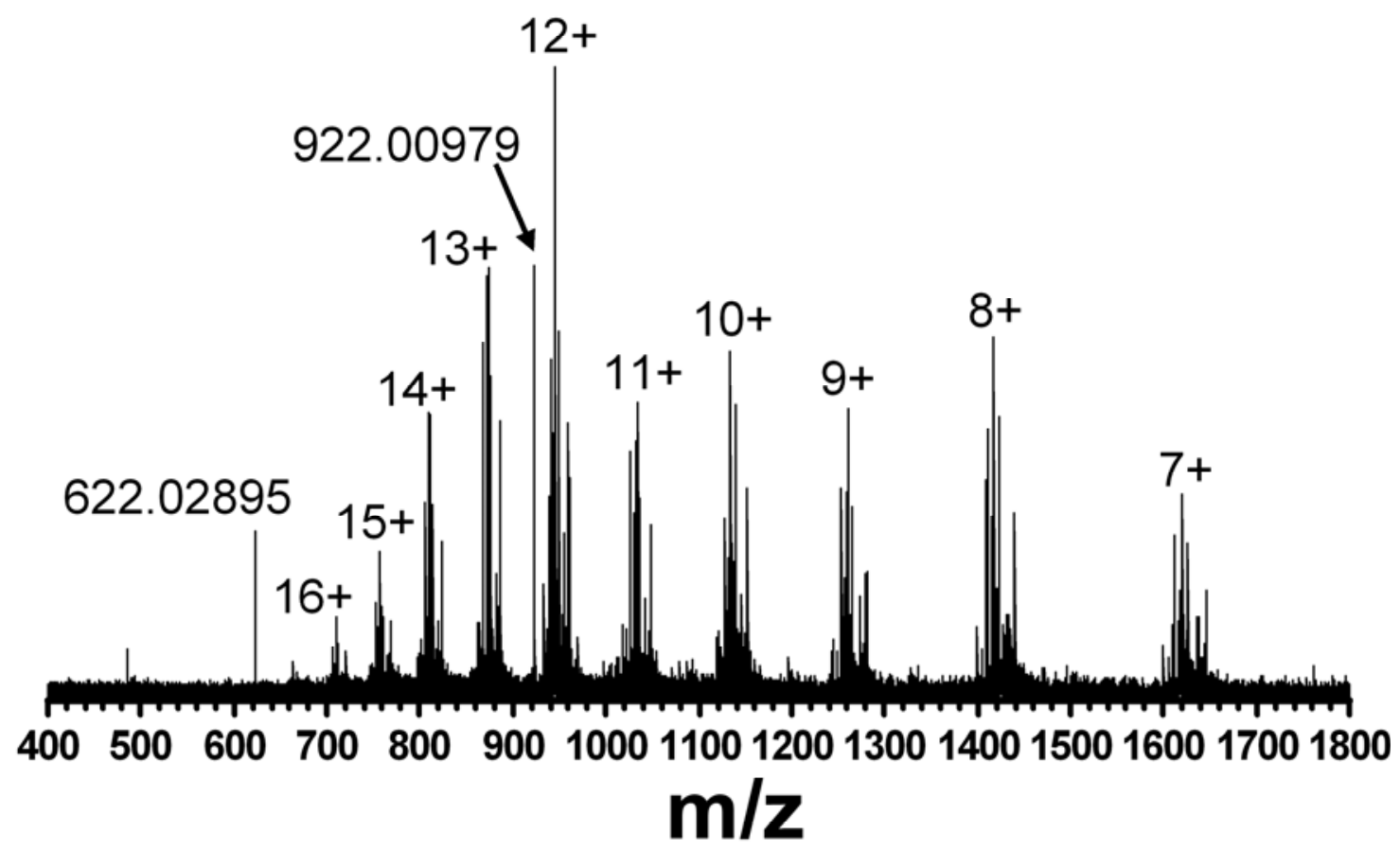

Figure 2. ESI-FTMS of $(R, S)$-HMG-holo-CurB treated with $\mathrm{ECH}_{1}$ and $\mathrm{ECH}_{2}$. A calibration standard was added for internal mass calibration, resulting in the peaks at $\mathrm{m} / \mathrm{z}=622.02895$ and 922.00979 .

\begin{tabular}{|c|c|c|c|}
\hline & Theoretical mass & $\begin{array}{c}\text { Experimental most } \\
\text { abundant mass }\end{array}$ & Error (ppm) \\
\hline $5-\mathrm{ACP}$ & 11325.83610 & $11325.82370 \pm 0.16$ & 1.09 \\
\hline 6 -ACP & 11307.82560 & $11307.82112 \pm 0.14$ & 0.40 \\
\hline $7-\mathrm{ACP}$ & 11263.83585 & $11264.83869 \pm 0.11$ & 0.25 \\
\hline
\end{tabular}

Table 1. Mass calibration results for HMG-holo-CurB and associated peaks corresponding to the loss of $\mathrm{H}_{2} \mathrm{O}$ and $\left(\mathrm{H}_{2} \mathrm{O}+\mathrm{CO}_{2}\right)$ from HMG-holo-CurB. The masses of the most abundant isotopes of the $8^{+}-15^{+}$charge states were used for mass calculation. 
A

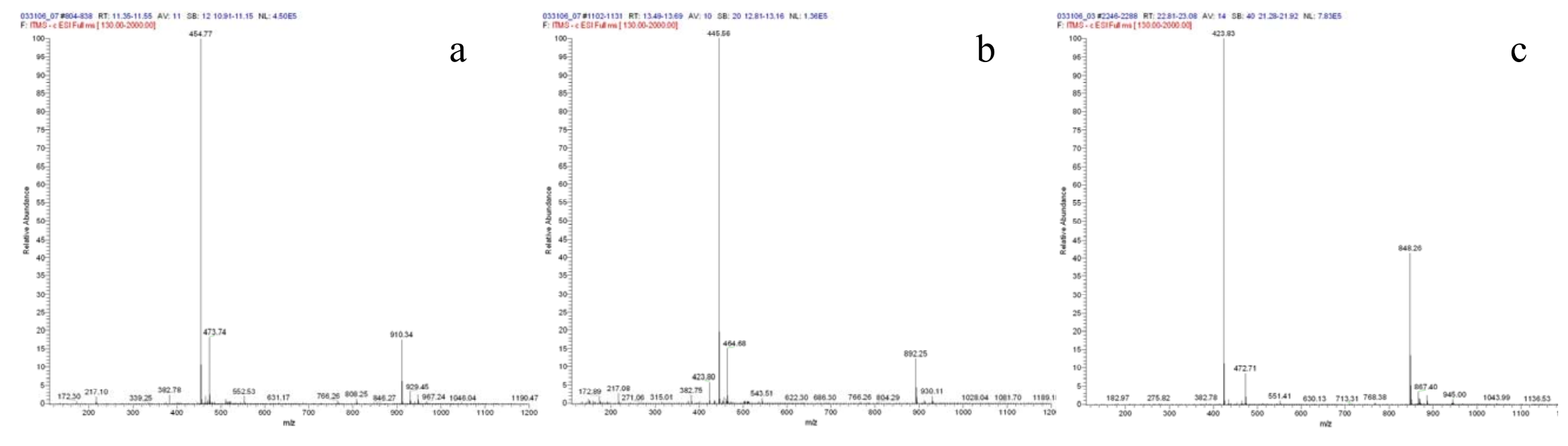

B

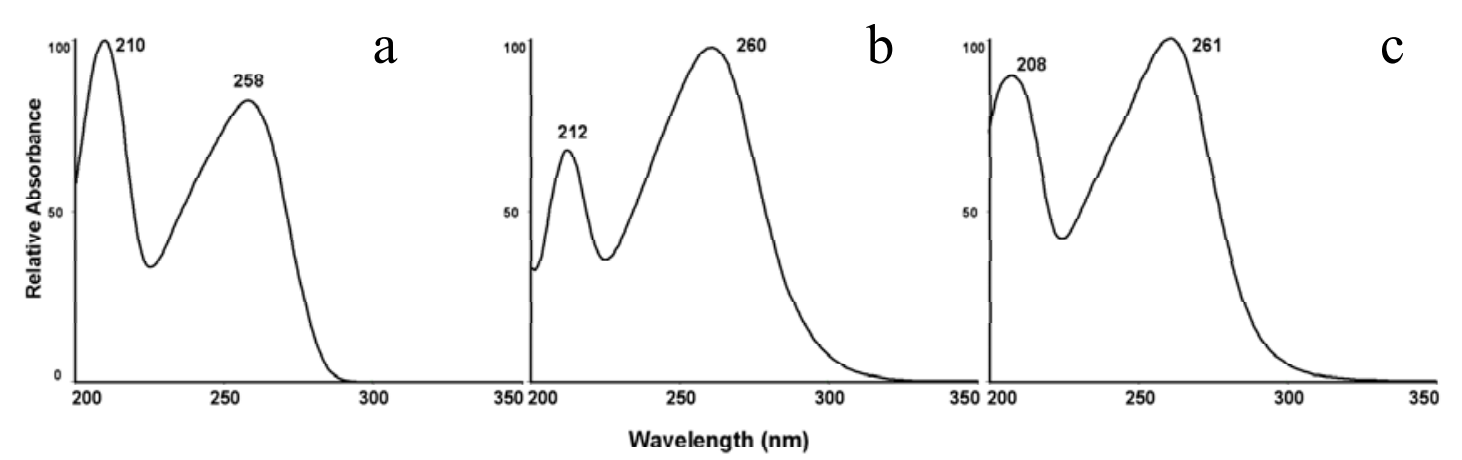

Figure 3. Mass spectra (A) and UV spectra (B) of 5 (HMG)-CoA (a), 6 (3-methylglutaconyl)-CoA (b) and 7 (3-methylcrotonyl)-CoA (c). The mass spectra and UV spectra were recorded at the retention times of the corresponding HPLC peaks after the background subtraction. 


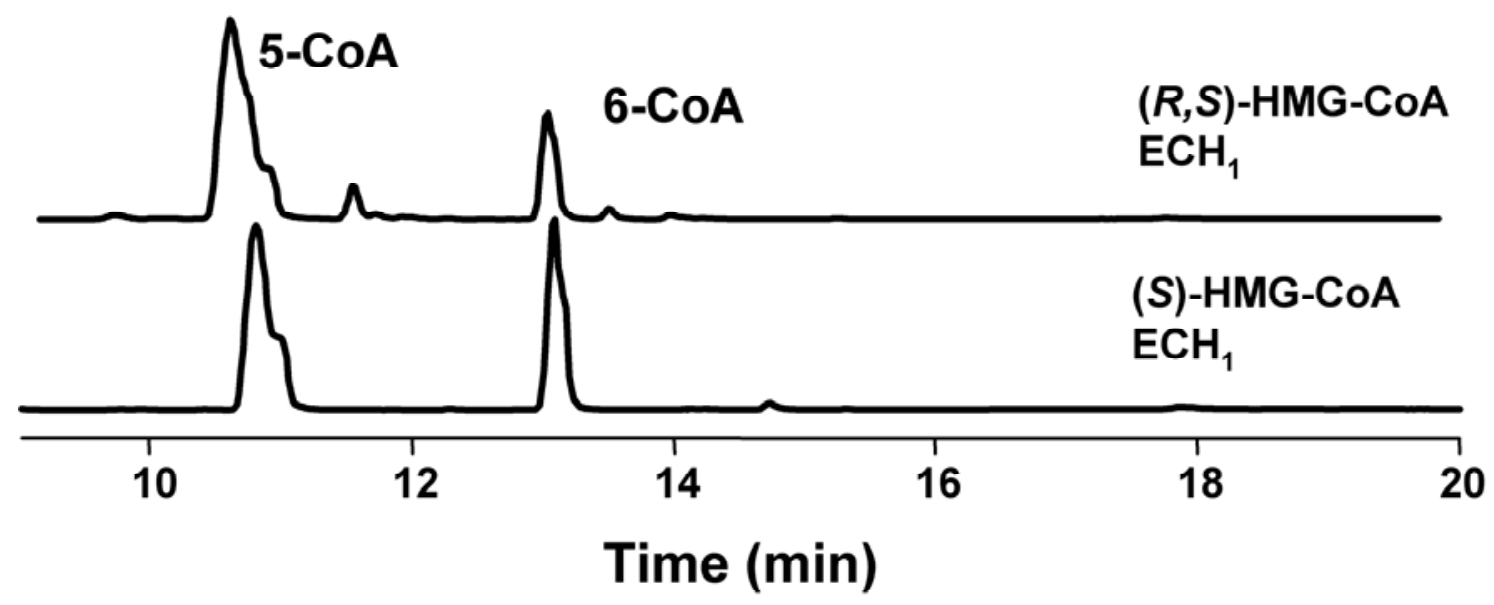

Figure 4. HPLC chromatograms at $275 \mathrm{~nm}$ for $\mathrm{ECH}_{1}$ assays using $(R, S)-\mathrm{HMG}-\mathrm{CoA}(\mathbf{a})$ and $(S)-\mathrm{HMG}-\mathrm{CoA}(\mathbf{b})$. Reaction conditions: $500 \mu \mathrm{M}$ HMG-CoA, $2 \mu \mathrm{M} \mathrm{ECH}$, at $37^{\circ} \mathrm{C}$ for 1.5 hours. 5-CoA: HMG-CoA, 6-CoA: 3-methylglutaconyl-CoA.

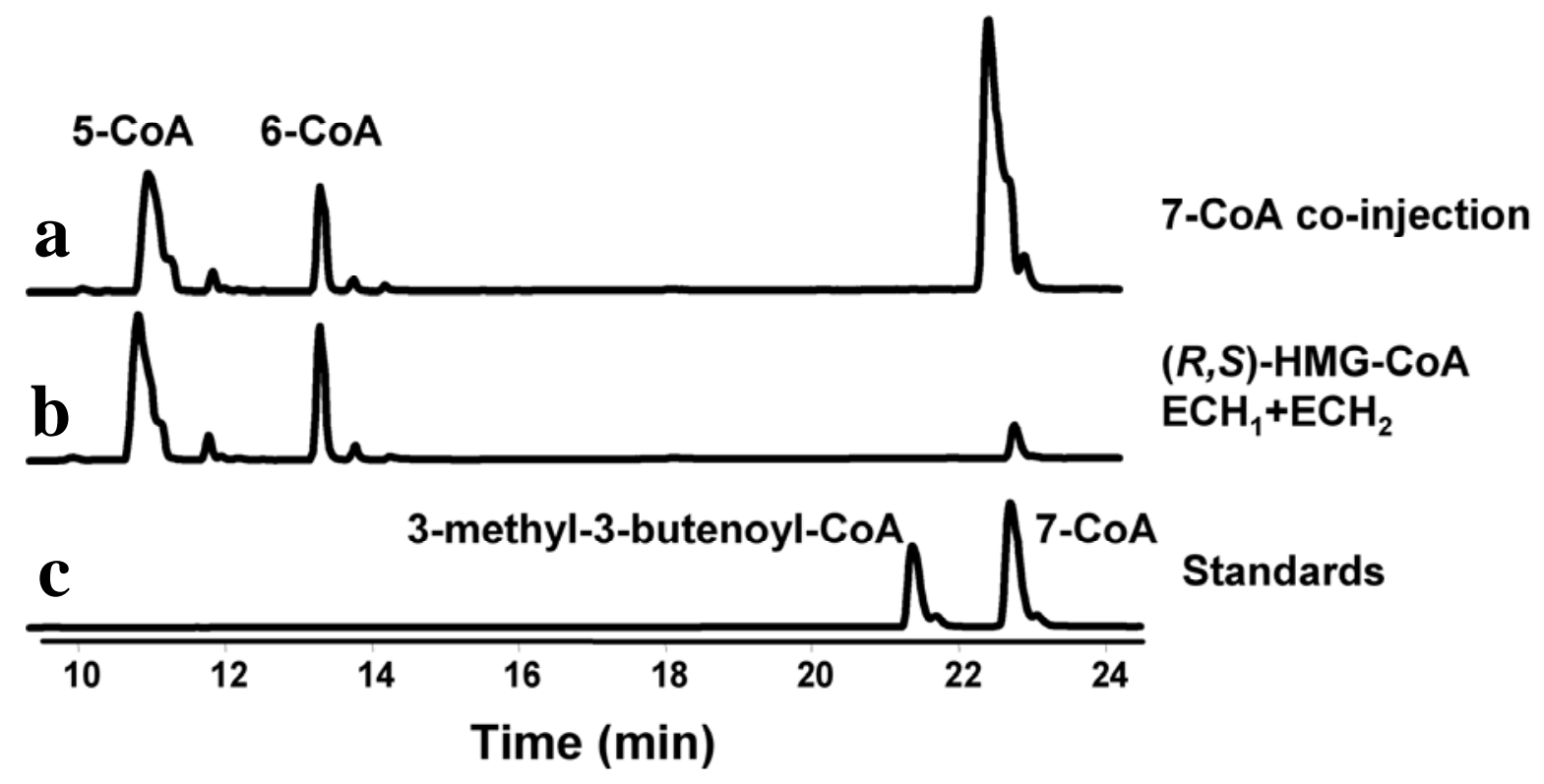

Figure 5. HPLC chromatograms at $260 \mathrm{~nm}$ for $\mathrm{ECH}_{1}$ and $\mathrm{ECH}_{1}$ assays and co-injection with the standards. (a) Standards: 7 (3-methylcrotonyl)-CoA and 3-methyl-3-butenoyl-CoA; (b). $\mathrm{ECH}_{1}+\mathrm{ECH}_{2}$ assay using $(R, S)$-HMG-CoA; (c) the co-injection of (b) and 7-CoA. 